\title{
PRESCRIBING PATTERN AND APPROPRIATENESS OF PRESCRIPTION AMONG ELDERLY PATIENTS IN A TERTIARY CARE HOSPITAL OF WESTERN NEPAL - A PROSPECTIVE CROSS- SECTIONAL STUDY
}

\author{
SAGARANANDA GIRI*, GULAM MUHAMMAD KHAN \\ Pharmaceutical Sciences Program, School of Health and Allied Sciences, Pokhara University, Kaski, Nepal. \\ Email: girisagarananda@gmail.com
}

Received: 12 January 2020, Revised and Accepted: 22 February 2020

\section{ABSTRACT}

Objective: The current study aims to evaluate prescribing pattern and potentially inappropriate medicine (PIM) among elderly patients in a tertiary care hospital of western Nepal.

Methods: A prospective cross-sectional study was conducted in the outpatient department of Manipal Teaching Hospital of Western Nepal. The World Health Organization prescribing indicators and Beers' 2015 updated criteria were assessed to analyze the result.

Results: The mean \pm standard deviation of the age was $73.47 \pm 6.42$ years and the majority of patients were in the age group $65-74$ (58.81\%). Male preponderance (male: female=1.20:1) was found. The value of prescribing indicator includes the average number of drug per prescription (4.91), percentage of generic name prescription (3.40\%), percentage of antimicrobials prescribed (19.40\%), percentage of injections prescribed (2.70\%), and percentage of the drug from essential drug list of Nepal (42.22\%). At least one PIM was prescribed to 87 (21.6\%) patients. Non-cyclooxygenaseselective nonsteroidal anti-inflammatory drugs (44\%) and anticholinergics (18\%) were the most frequently prescribed PIMs.

Conclusions: Polypharmacy, PIMs, and potential drug-drug interaction were prevalent in this study. It is recommended that all the doctors, pharmacists, other concerned health-care professionals, patients, policymakers, and all other stakeholders must be aware of these situations and a multidisciplinary approach must be developed for the promotion of rational use of drugs.

Keywords: Beers Criteria, Elderly patients, Polypharmacy, Potentially inappropriate medicine, Prescribing pattern.

(C) 2020 The Authors. Published by Innovare Academic Sciences Pvt Ltd. This is an open access article under the CC BY license (http://creativecommons. org/licenses/by/4. 0/) DOI: http://dx.doi.org/10.22159/ajpcr.2020.v13i4.36843

\section{INTRODUCTION}

In this $21^{\text {st }}$ century, there is an increment in the life expectancy of the majority of the population around the world; due to improved nutrition, sanitation, medical advances, health care, education, and economic wellbeing [1]. The global population of the older population is projected to reach nearly 2.1 billion by 2050 [2]. The census of 2012 showed the presence of $5.28 \%$ of elderly people aged $\geq 65$ years in Nepal [3].

Elderly people aged over 65 years are generally more likely to be on multiple medication or polypharmacy than younger people as they have a higher prevalence of chronic illness, disability, and dependency $[4,5]$. Due to reasons such as multiple comorbidities and multiple prescribing habits of physicians, polypharmacy is an increasingly serious global problem in the current health-care system. Polypharmacy in the elderly exposes them to adverse consequences such as greater health-care costs, increased risk of adverse drug events, drug-drug interactions (DDIs), medication non-adherence, reduced functional capacity, and multiple geriatric syndromes [6-8].

A potentially inappropriate medication (PIM) is defined as a drug in which the risks associated with prescribing it outweigh its potential benefits, particularly when safer alternatives exist. Inappropriate prescribing causes high cost of treatment, ineffective, unsafe treatment, exacerbation or prolongation of illness, distress, and harm to the patient [9]. Polypharmacy and PIM are commonly encountered scenarios in Nepal $[10,11]$. Evaluating drug prescribing pattern provides advantageous feedback to prescribers to improve their prescribing behavior and help the policymakers to set the priorities to promote the rational use of medicines nationwide [9]. The Beers Criteria are the most commonly used method for assessing the appropriateness of prescribed drugs for older people in all clinical settings [12-14]. Therefore, this study is aimed to determine the current prescribing pattern and inappropriate prescribing in the elderly population in the western part of Nepal.

\section{METHODS}

The study was a prospective cross-sectional study which was conducted in the outpatient department of Manipal Teaching Hospital, Pokhara, Nepal. Patients of all gender and age 65 years and above, who attended the various outpatient departments and hospital pharmacy for purchasing medicines, were included in this study with written consent.

The data were collected from August 2018 to November 2018. The study was approved by Institutional Review Committee (IRC), Pokhara University Research Centre Kaski, Nepal.

Data were collected in a structured pro forma, which include the patient's demographic details (age and sex) and the department visited by the patient. Diseases and drugs were classified according to the international classification of diseases-10 and the anatomical therapeutic chemical classification, respectively $[15,16]$.

The World Health Organization (WHO) prescribing indicators were assessed such as (1) Average number of the drugs per prescription, (2) percentage of the drugs prescribed by generic name, (3) percentage of prescriptions with antimicrobial(s) prescribed, (4) percentage of prescriptions with injection(s) prescribed, and (5) percentage of the drugs prescribed from an essential drug list. National list of essential medicines, Nepal (2016), was used to find out the percentages of drugs prescribed from the lists $[17,18]$. The prevalence of polypharmacy 
Table 1: Age class of the patients

\begin{tabular}{|c|c|c|c|c|c|}
\hline \multirow[t]{2}{*}{ Age class } & \multicolumn{2}{|l|}{ Gender } & \multirow[t]{2}{*}{ Frequency } & \multirow[t]{2}{*}{ Percentage } & \multirow[t]{2}{*}{ Average number of drugs } \\
\hline & Male $(n=220,54.59 \%)$ & Female $(n=183,45.41 \%)$ & & & \\
\hline $65-74$ & 118 & 119 & 237 & 58.81 & 4.77 \\
\hline$\geq 85$ & 15 & 15 & 30 & 7.44 & 5.20 \\
\hline
\end{tabular}

Table 2: Number of medication per prescription

\begin{tabular}{lll}
\hline Number of medicine prescribed & Frequency & Percentage \\
\hline 1.0 & 20 & 4.96 \\
2.0 & 45 & 11.17 \\
3.0 & 71 & 17.62 \\
4.0 & 69 & 17.12 \\
5.0 & 60 & 14.89 \\
6.0 & 38 & 9.43 \\
7.0 & 35 & 8.68 \\
8.0 & 23 & 5.71 \\
9.0 & 22 & 5.46 \\
10.0 & 9 & 2.23 \\
11.0 & 4 & 0.99 \\
12.0 & 3 & 0.74 \\
13.0 & 1 & 0.25 \\
14.0 & 2 & 0.50 \\
15.0 & 1 & 0.25 \\
\hline
\end{tabular}

$\%$ Calculated from a total of 403 patients

Table 3: Drug prescribing pattern in elderly patients using the WHO core drug indicator

\begin{tabular}{ll}
\hline Prescribing indicators & Findings (\%) \\
\hline Average number of drugs per prescription & 4.91 \\
Percentage of drugs prescribed by generic name & 3.40 \\
Percentage of prescriptions with antimicrobial(s) & 19.40 \\
Percentage of prescriptions with injection(s) & 2.70 \\
Percentage of drugs prescribed from national & 42.22 \\
essential drug list & \\
\hline
\end{tabular}

(5-9 medications) and high-level polypharmacy ( $\geq 10$ medications) was determined. Inappropriate medications for older adults were identified using Beers' 2015 updated criteria. The DDIs were checked using Medscape drug interaction checker $[10,19,20]$. All the data were entered in Microsoft Excel version 2013 and analyzed using Statistical Package for the Social Science version 20.

\section{RESULTS}

\section{Demographics}

A total of 403 patients were enrolled in this study. Of which 220 were male $(54.59 \%)$ and 183 were female (45.41\%). The overall mean \pm standard deviation of age was $73.47 \pm 6.43$ years. The majority of the patients were in the age group 65-74 (58.81\%) followed by age group 75-84 (33.75\%) and $\geq 85(7.44 \%)$. The mean number of drugs prescribed within the age group of 65-74 years was 4.77 , for those within the age group 75-84 was 5.10 and within the age group of $\geq 85$ years was 5.20 as shown in Table 1 .

Number of medication per prescription and polypharmacy Most of the patients were prescribed with three medicine followed by four and least were taking 15 medicine. Among 198 (49.13\%) patients with polypharmacy, high-level polypharmacy was present on $20(4.96 \%)$ patients, as shown in Table 2.

Drug prescription pattern in elderly patients using the WHO core drug indicator

The total number of drug prescribed to 403 patients was 1980, with an average of $4.91 \pm 2.56$ per person. The prescribing pattern evaluated based on the WHO core drug use indicator is shown in Table 3.
Table 4: Department wise categorization of prescription

\begin{tabular}{lll}
\hline Department & Frequency & Percentage \\
\hline Medicine & 277 & 68.73 \\
Orthopedics & 63 & 15.63 \\
Surgery & 38 & 9.43 \\
Ear, nose and throat & 22 & 5.46 \\
Eye & 20 & 4.96 \\
Dermatology & 17 & 4.22 \\
Psychiatric & 15 & 3.72 \\
\hline
\end{tabular}

$\%$ Calculated from a total of 403 patients

\section{Department wise categorization of prescription}

In this study, most of the enrolled patients were from the medicine department $(68.73 \%)$ followed by orthopedics $(15.63 \%)$ and surgery (9.43\%), as shown in Table 4.

Prevalence of disease conditions among elderly patients

Diseases from the circulatory system $(271,67.25 \%)$ were the most prevalent in which hypertensive patients were 163. Diseases of the circulatory system were followed by endocrine, nutritional and metabolic diseases $(91,22.58 \%)$, and respiratory system $(87,21.59 \%)$, respectively. The disease classification and comorbidities are shown in Table 5.

\section{Medicines mainly prescribed in elderly}

Most drugs prescribed were cardiovascular (29.75\%) followed by those of alimentary tract and metabolism $(24.09 \%)$. The detailed classification of drug prescribed is shown in Table 6.

\section{PIM use for the elderly based on Beers Criteria}

In the total of 1980 drugs prescribed, 100 (5.05\%) were found to be potentially inappropriate. At least one case of PIM prescription was found in every $87(21.6 \%)$ cases. Non-cyclooxygenase-selective nonsteroidal anti-inflammatory drugs (NSAIDs) (44\%) followed by anticholinergics (18\%) were most frequently prescribed, as shown in Table 7.

Most frequently prescribed drugs with potential DDI

All the prescriptions were checked for DDI using Medscape drug interaction checker and $210(52.10 \%)$ of the prescription were detected with at least one potential DDI, as shown in Table 8. Pantoprazole and digoxin was the most frequently prescribed drug with potentially serious DDIs. All the interaction listed in Table 8 has the possibility of interaction requiring caution and monitoring.

\section{DISCUSSION}

The drug prescription for elderly people affected with multiple chronic diseases with the lurking cases of polypharmacy is a challenging task [20]. Polypharmacy and the prescription of PIMs were frequently encountered among elderly patients enrolled in this study. Among 403 patients enrolled in this study, male preponderance (male: female=1.20:1) was seen in accordance with studies of Basnet et al., (1.10:1) [10], Sah et al., (1.95:1) [20], and Rakesh et al., (1.03:1)[21]. The possible reason for male preponderance can be due to easy access to medications, awareness, and comparatively good economic liberty of males in South Asian countries, including Nepal [22].

In this study, the majority of individual patients were found to be administered with three medicines at a time while some were found 
Table 5: Prevalence of disease conditions among elderly patients

\begin{tabular}{|c|c|c|c|}
\hline Disease group & Specific condition & Number & Total (percentage of comorbidity) \\
\hline \multirow[t]{2}{*}{ Circulatory system } & Hypertension & 163 & $271(67.25)$ \\
\hline & Others & 108 & \\
\hline \multirow{2}{*}{$\begin{array}{l}\text { Endocrine, nutritional, and metabolic } \\
\text { diseases }\end{array}$} & Diabetes mellitus & 64 & $91(22.58)$ \\
\hline & Endocrine disorder & 27 & \\
\hline \multirow[t]{2}{*}{ Respiratory system } & Chronic obstructive respiratory disease & 57 & $87(21.59)$ \\
\hline & Others & 30 & \\
\hline \multirow{2}{*}{$\begin{array}{l}\text { Musculoskeletal system and connective } \\
\text { tissue }\end{array}$} & Rheumatoid arthritis & 7 & $70(17.37)$ \\
\hline & Others & 63 & \\
\hline \multirow[t]{2}{*}{ Digestive system } & Peptic ulcer, gastritis, and duodenitis & 20 & $44(10.92)$ \\
\hline & Others & 24 & \\
\hline \multirow[t]{3}{*}{ Genitourinary system } & Benign prostatic hyperplasia & 15 & $39(9.68)$ \\
\hline & Renal failure & 8 & \\
\hline & Others & 16 & \\
\hline \multirow[t]{3}{*}{ Eye and adnexa } & Conjunctivitis & 6 & $25(6.20)$ \\
\hline & Cataract & 5 & \\
\hline & Others & 14 & \\
\hline Nervous system & Sleep disorders and others & 17 & $17(4.22)$ \\
\hline Certain infectious and parasitic diseases & Bacterial, viral, and other infections & 17 & $17(4.22)$ \\
\hline Skin and subcutaneous tissue & Urticaria, erythema, and others & 14 & $14(3.47)$ \\
\hline $\begin{array}{l}\text { Symptoms, signs and abnormal clinical and } \\
\text { laboratory findings, not elsewhere classified }\end{array}$ & Anorexia and other & 12 & $12(2.98)$ \\
\hline Mental and behavioral disorders & Schizophrenia and others & 9 & $9(2.23)$ \\
\hline Ear and mastoid process & Disorder of internal, middle, and external ear & 6 & $6(1.49)$ \\
\hline $\begin{array}{l}\text { Blood and blood-forming organs and certain } \\
\text { disorders involving the immune mechanism }\end{array}$ & Anemia & 5 & $5(1.24)$ \\
\hline
\end{tabular}

Table 6: Medicines mainly prescribed in elderly

\begin{tabular}{|c|c|c|c|c|}
\hline \multirow{5}{*}{$\begin{array}{l}\text { Anatomical therapeutic } \\
\text { chemical system main group } \\
\text { Alimentary tract and metabolism }\end{array}$} & \multicolumn{2}{|c|}{ Medicines mainly used } & \multirow{2}{*}{$\begin{array}{l}\text { No. of drugs } \\
209\end{array}$} & \multirow{2}{*}{$\begin{array}{l}\text { Total (percentage) } \\
477(24.09)\end{array}$} \\
\hline & A02BC & Proton pump inhibitors & & \\
\hline & A10 & Drugs used in diabetes & 95 & \\
\hline & $\mathrm{A} 12$ & Mineral supplements & 81 & \\
\hline & Others & & 92 & \\
\hline \multirow[t]{3}{*}{ Blood } & B01AC & Platelet aggregation inhibitors excl. heparin & 128 & $197(9.95)$ \\
\hline & B03 & Antianemic preparations & 24 & \\
\hline & Others & & 45 & \\
\hline \multirow[t]{7}{*}{ Cardiovascular } & C01DA & Organic nitrates & 21 & $589(29.75)$ \\
\hline & $\mathrm{C} 03$ & Diuretics & 118 & \\
\hline & $\mathrm{C} 07$ & Beta blocking agents & 99 & \\
\hline & $\mathrm{C} 08$ & Calcium channel blockers & 59 & \\
\hline & C09 & Agents acting on renin-angiotensin system & 132 & \\
\hline & C10AA & HMG CoA reductase inhibitors & 113 & \\
\hline & Others & & 47 & \\
\hline \multirow[t]{3}{*}{ Derma } & D01 & Antifungals for dermatological use & 11 & $25(1.26)$ \\
\hline & D07 & Corticosteroids, dermatological preparations & 7 & \\
\hline & Others & & 7 & \\
\hline Genitourinary system & G04 & Urologicals & 37 & 37 (1.87) \\
\hline Systemic & $\mathrm{H} 02$ & Corticosteroids for systemic use & 18 & 37 (1.87) \\
\hline \multirow{4}{*}{ Anti-infective } & H03 & Thyroid therapy & 19 & \\
\hline & J01C & Beta-lactam antibacterials, penicillins & 22 & $102(5.15)$ \\
\hline & $\mathrm{J} 01 \mathrm{~F}$ & Macrolides, lincosamides, and streptogramins & 18 & \\
\hline & Others & & 62 & \\
\hline Antineoplastic & L01 & Antineoplastic agents & 2 & $2(0.10)$ \\
\hline \multirow[t]{2}{*}{ Musculoskeletal } & M01A & Anti-inflammatory and antirheumatic products, nonsteroids & 67 & $118(5.96)$ \\
\hline & Others & & 51 & \\
\hline \multirow[t]{3}{*}{ Nervous System } & NO2 & Analgesics & 40 & $121(6.11)$ \\
\hline & N03 & Antiepiletics & 33 & \\
\hline & Others & & 48 & \\
\hline Antiparasitic & P02 & Antihelmintics & 10 & $10(0.51)$ \\
\hline Respiratory & R03 & Drugs for obstructive airway diseases & 133 & $218(11.01)$ \\
\hline \multirow{3}{*}{ Sensory } & Others & & 85 & \\
\hline & S01 & Opthalmologicals & 28 & 47 (2.37) \\
\hline & Others & & 19 & \\
\hline
\end{tabular}

$\%$ Calculated from a total of 1980 drugs 
to be administered with four. These findings were similar to the study conducted by Kanagasanthosh et al., in which the majority of patients were administered with two medications and to a lesser content were administered with three, four, and five medicines [23]. The difference in the number of medicines in this study might be due to many factors such as the case of ailments and trends in prescription patterns [24].

With regard to the WHO drug prescribing indicator, the average number of drugs prescribed per individual in this study (4.91) was found concordant with another study conducted in Nepal (5.56) [20] and in India (4.8) [21]. However, the finding was higher than that found in Turkey $(2.9 \pm 2.0)[25]$ and lower than that found in Argentina (6.1 \pm 2.7 ) [26]. The higher number of drugs prescribed can be stated as a practice of polypharmacy, which has been repeatedly found in various studies conducted in Nepal $[10,20]$. The percentage of medicines prescribed by their generic names was found to be $3.40 \%$ which was, however, found to be higher in similar studies carried out in India (12.60\%) [27] and in Pakistan (56.6\%) [28]. The decrement in the rate of prescription of medicines by their generic names can be due to the inefficient practice of prescribing medicines by their brand names for the sake of business. Prescribing by generic name allows flexibility of stocking and dispensing various brands of a particular drug that is cheaper than but as effective as proprietary brands [27].

In this study, percentage of antibiotics prescribed during the study period was found to be $19.40 \%$ which was similar to the findings of Sapkota et al., (18\%) [11] in Nepal but higher than that found by Taskeen et al., (3.62\%) [29] in India. The judicial use of antibiotic is important to prevent the emergence of resistance and is recommended to be prescribed only after sample culture and sensitivity test [23]. Percentage of prescriptions with injection(s) being prescribed in this study was found to be $2.70 \%$, which is lower than that found in a study conducted in India (26.33\%) [23] but higher than that found in a study in Nigeria $(0.8 \%)$ [30]. The possible reason for minimum cases of prescription of injection in this study may be due to the fact that the patients enrolled were of the outpatient department and injections were prescribed only for diabetic patients. Patient factor, cost factor, prescriber's habit, and risk of infection through the parenteral route often affect the prescription of injection(s) [23].

Percentage of medicines prescribed which belong to the national essential medicines list was found to be $42.44 \%$ which was lower than that found in a study carried out in Kathmandu, Nepal (75\%)[11] and also lower than the result found in a study in Pakistan (98.8\%) [28]. It is recommended to make usage of drugs enlisted in the essential drug list so that optimal use of limited financial resources takes place and also to have acceptable safety and satisfaction of the health needs of the majority of the population [11]. The reason for least number of medicines prescribed from the essential medicine list could be related to a lack of awareness about essential drug concept and essential drug list among prescribers along with irrational prescribing habits $[11,31]$.

In this study, most commonly visited departments by elderly patients were found to be of medicine $(68.73 \%)$ and orthopedics (15.63\%); this finding was similar to that of a study in India where elderly patients most commonly visited the medicine department (28.83\%), which was followed by the orthopedic department (25\%) and cardiology department (15.83\%) [23]. This pattern of patients visiting respective departments can be attributed to the fact that most of the patients in the study were suffering from hypertension, diabetes mellitus, chronic obstructive respiratory disease, and metabolic disorders.

Cases of polypharmacy were found common among $49.10 \%$ of patients enrolled in this study; this value was found to be lower than that found in a study conducted in Bharatpur, Chitwan, Nepal (86.66\%) [10] but greater than that found in a study in Italy (39.4\%) [32]. Along with polypharmacy, multiple comorbidities were found among the patients. In this study, most of the patients were suffering from hypertension $(\mathrm{n}=163,40.45 \%)$, ischemic heart disease, and other cardiovascular diseases $(n=108,26.80 \%)$ and also from diabetes mellitus $(n=64$, $15.88 \%$ ). These findings were similar to the findings of another study carried out in Nepal and India $[20,21]$. Polypharmacy is common in the elderly due to multiple comorbidities and inappropriate prescribing trends among physicians [7]. Most of the drugs prescribed in this study were from Group C (cardiovascular drugs - 589, 29.75\%), Group A (alimentary and metabolism drugs - 477, 24.09\%), and Group R (respiratory drugs $-218,11.01 \%$ ). This is similar to the findings in another study conducted by Basnet et al., in Nepal [10]. These kinds of prescriptions can be due to the fact that most of the patients in the study were suffering from circulatory, endocrine-metabolic, and respiratory disorders.

Of total 403 prescriptions in this study, 87 (21.6\%) prescriptions were found to be potentially inappropriate which was similar to the findings of studies conducted in Nepal (26.3\%) [20], India (19.9\%)[21], and Netherland (20\%) [33]. However, it was lower than that found by another study in Nepal conducted by Basnet et al., which demonstrated $34.67 \%$ inappropriate prescriptions [10]. This study also shows that NSAIDs were commonly encountered class of PIMs which constitute $44 \%$ of total cases; this finding is similar to that reported in India (30.66\%) [23].

This study also shows that $210(52.10 \%)$ of the total prescriptions had drug interactions which are similar to the findings of another study done in Nepal that showed $48.9 \%$ drug interaction cases [10]. This study had one case of contraindicated reaction and 36 cases of serious interactions. Digoxin-pantoprazole was the frequently prescribed combination (11 patients) having potential DDIs. The possible reason for the higher DDI might be due to the cases of multiple comorbidities, polypharmacy, and multiple prescriptions by physicians [7].

Table 7: Potentially inappropriate medication use for the elderly based on Beers Criteria

\begin{tabular}{|c|c|c|c|}
\hline \multicolumn{4}{|c|}{ Medications and class to avoid in older adults } \\
\hline $\begin{array}{l}\text { Category of } \\
\text { drugs }\end{array}$ & Name of drug & $\begin{array}{l}\text { Number } \\
\text { of drugs }\end{array}$ & $\begin{array}{l}\text { Frequency } \\
\text { (\%) }\end{array}$ \\
\hline \multirow[t]{4}{*}{ Anticholinergics } & Chlorpheniramine & 6 & \multirow[t]{4}{*}{18} \\
\hline & Cyproheptadine & 5 & \\
\hline & Hydroxyzine & 3 & \\
\hline & Triprolidine & 4 & \\
\hline $\begin{array}{l}\text { Antiparkinsonian } \\
\text { agents }\end{array}$ & Trihexyphenidyl & 2 & 2 \\
\hline Anti-infective & Nitrofurantoin & 4 & 4 \\
\hline \multirow[t]{2}{*}{ Benzodiazepines } & Alprazolam & 1 & \multirow[t]{2}{*}{7} \\
\hline & Clonazepam & 6 & \\
\hline \multirow[t]{4}{*}{ Cardiovascular } & Prazosin & 5 & \multirow[t]{4}{*}{13} \\
\hline & Methyldopa & 3 & \\
\hline & Digoxin ( $>0.125 \mathrm{mg} /$ day) & 1 & \\
\hline & Amiodarone & 4 & \\
\hline \multirow{3}{*}{$\begin{array}{l}\text { Central nervous } \\
\text { system }\end{array}$} & Amitriptyline & 4 & \multirow[t]{3}{*}{7} \\
\hline & Nortriptyline & 2 & \\
\hline & Paroxetine & 1 & \\
\hline \multirow{5}{*}{$\begin{array}{l}\text { Non- } \\
\text { cyclooxygenase- } \\
\text { selective NSAIDs }\end{array}$} & Diclofenac & 10 & \multirow{5}{*}{44} \\
\hline & Ibuprofen & 1 & \\
\hline & Naproxen & 15 & \\
\hline & Indomethacin & 4 & \\
\hline & Ketorolac & 14 & \\
\hline $\begin{array}{l}\text { Skeletal muscle } \\
\text { relaxants }\end{array}$ & Chlorzoxazone & 5 & 5 \\
\hline
\end{tabular}

\% Calculated from 100 PIMs drugs 
Table 8: Most frequently prescribed drugs with potential drug-drug interaction

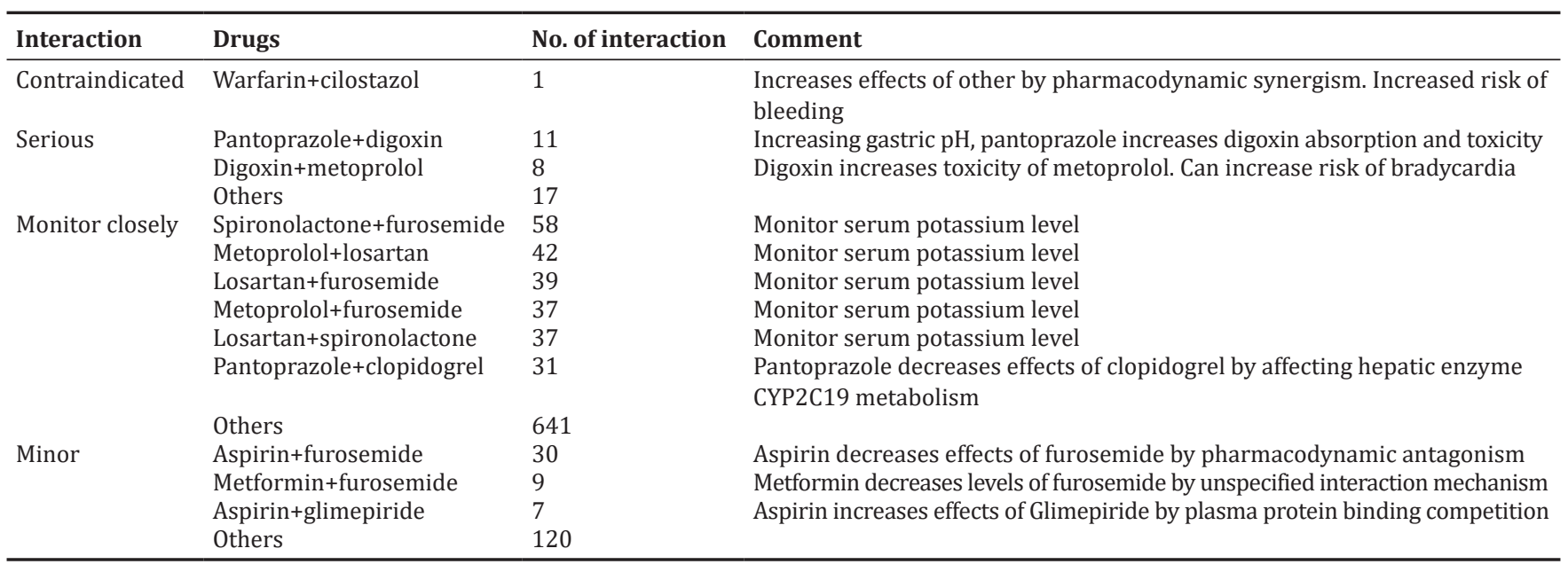

\section{CONCLUSIONS}

Polypharmacy and prescription of inappropriate medication with potential DDI were observed in this study. The cases of prescriptions by generic names were found to be low, and thus efforts to encourage prescribing by generic name should be initiated. It is recommended that all the doctors, pharmacists, other concerned health-care professionals, patients, policymakers, and all other stakeholders must be aware of these situations and a multidisciplinary approach must be developed for the promotion of rational use of drugs.

\section{ACKNOWLEDGMENTS}

The author expresses sincere gratitude to the Dean, Director, Program Coordinator, and Faculty of Pharmaceutical Sciences, Pokhara University, for their encouragement and support during this research work. Heartfelt thanks to the team of Pharmacy Department of Manipal Teaching Hospital for their kind cooperation during this research work.

\section{AUTHORS' CONTRIBUTIONS}

Sagarananda Giri, conception, data collection, data analysis, interpretation, and drafting of the article. Gulam Muhammad Khan conceptualized the study design and proofreading of the manuscript.

\section{CONFLICTS OF INTEREST}

The authors declare that they have no conflicts of interest.

\section{REFERENCES}

1. UNFPA. Ageing in the Twenty First Century: Report. A Celebration and Challenges; 2012. Available from: https://www.unfpa.org/publications/ ageing-twenty-first-century. [Last accessed on 2018 Nov 20].

2. United Nations, Department of Economic and Social Affairs, Population Division. World Population Ageing (ST/ESA/SER. A/390); 2015. Available from: https://www.un.org/en/development/desa/population/ publications/pdf/ageing/wpa2015_report.pdf. [Last accessed on 2018 Nov 20].

3. Central Bureau of Statistics. National Population and Housing Census 2011. Vol. 1. Kathmandu, Nepal: Central Bureau of Statistics; 2012. Available from: https://www.unstats.un.org/unsd/demographic-social/ census/documents/nepal/nepal-census-2011-vol1.pdf. [Last accessed on 2018 Nov 21].

4. World Health Organization. Definition of an Older or Elderly Person. Geneva: World Health Organization; 2013. Available from: https:// www.who.int/healthinfo/survey/ageingdefnolder/en/. [Last accessed on 2018 Nov 22]

5. Gallagher P, Barry P, O'Mahony D. Inappropriate prescribing in the elderly. J Clin Pharm Ther 2007;32:113-21.

6. Bushardt RL, Massey EB, Simpson TW, Ariail JC, Simpson KN.
Polypharmacy: Misleading, but manageable. Clin Interv Aging 2008;3:383-9.

7. Romana A, Kamath L, Sarda A, Muraraiah S, Jayanthi CR. Polypharmacy leading to adverse drug reactions in elderly in a tertiary care hospital. Int J Pharma Bio Sci 2012;3:218-24.

8. Khandeparkar A, Rataboli PV. A study of harmful drug-drug interactions due to polypharmacy in hospitalized patients in Goa Medical College. Perspect Clin Res 2017;8:180-6.

9. Pavani V, Shravani K, Prabhakar RV. Study of prescribing pattern for evaluation of rational drug therapy in Warangal. Indian J Pharm Pract 2011;4:77-9.

10. Basnet S, Paudel KR, Sah AK, Jha RK, Sah P, Adhikari S, et al. Prescribing pattern, polypharmacy and potentially inappropriate prescribing in hospitalized elderly patients: A retrospective study in a teaching hospital in Nepal. Int J Sci Rep 2016;2:7-12.

11. Sapkota S, Pudasaini N, Singh C, Sagar GC. Drug prescribing pattern and prescription error in elderly: A retrospective study of inpatient record. Asian J Pharm Clin Res 2011;4:129-32.

12. Hill-Taylor B, Sketris I, Hayden J, Byrne S, O'sullivan D, Christie R. Application of the STOPP/START criteria: A systematic review of the prevalence of potentially inappropriate prescribing in older adults, and evidence of clinical, humanistic and economic impact. J Clin Pharm Ther 2013;38:360-72.

13. Galli TB, Reis WC, Andrzejevski VM. Potentially inappropriate prescribing and the risk of adverse drug reactions in critically ill older adults. Pharm Pract (Granada) 2016;14:1-7.

14. Pasina L, Djade CD, Tettamanti M, Franchi C, Salerno F, Corrao S, et al. Prevalence of potentially inappropriate medications and risk of adverse clinical outcome in a cohort of hospitalized elderly patients: Results from the REPOSI Study. J Clin Pharm Ther 2014;39:511-5.

15. World Health Organization. International Statistical Classification of Diseases and Related Health Problems: $10^{\text {th }}$ Revision (ICD-10). Geneva: World Health Organization; 2018. Available from: http://www.who.int/ classifications/apps/icd/icd.1992. [Last accessed on 2018 Nov 23].

16. World Health Organization. Anatomical Therapeutic Chemical (ATC) Classification. Geneva: World Health Organization; Available from: https://www.who.int/medicines/regulation/medicines-safety/toolkit atc/en/. [Last accessed on 2018 Nov 23].

17. World Health Organization. How to Investigate Drug Use in Health Facilities: Selected Drug Use Indicators. Geneva: World Health Organization; 1993.

18. National List of Essential Medicines, Nepal; 2016. Available from: http://www.apps.who.int/medicinedocs/documents/s23537en/ s23537en.pdf. [Last accessed on 2018 Nov 24].

19. The American Geriatrics Society 2015 Beers Criteria Update Expert Panel. American geriatrics society 2015 updated beers criteria for potentially inappropriate medication use in older adults. J Am Geriatr Soc 2015;63:2227-46.

20. Sah AK, Jha RK, Sah P, Basnet S. Potentially inappropriate prescribing in elderly population: A study in medicine out-patient department. J Coll Med Sci Nepal 2017;13:197-202.

21. Rakesh KB, Chowta MN, Shenoy AK, Shastry R, Pai SB. Evaluation of polypharmacy and appropriateness of prescription in geriatric patients: 
A cross-sectional study at a tertiary care hospital. Indian J Pharmacol 2017;49:16-20.

22. Mainuddin AK, Begum HA, Rawal LB, Islam A, Islam SS. Women empowerment and its relation with health seeking behavior in Bangladesh. J Family Reprod Health 2015;9:65-73.

23. Kanagasanthosh K, Topno I, Aravindkumar B. Prevalence of potentially inappropriate medication use and drug utilization pattern in elderly patients: A prospective study from a tertiary care hospital. Int J Res Med Sci 2015;3:2062-72.

24. Sharifnia SH, Mohammadzadeh M, Arzani G, Salamzadeh J, Abolfazli SA, et al. Main factors affecting physicians' prescribing decisions: The Iranian experience. Iran J Pharm Res 2018;17:1105-15.

25. Ay P, Akici A, Harmanci H. Drug utilization and potentially inappropriate drug use in elderly residents of a community in Istanbul, Turkey. Int J Clin Pharmacol Ther 2005;43:195-202.

26. Marzi MM, Diruscio VA, Núñez MH, Pires MS, Quaglia NB. Analysis of medication prescription in an Argentinian geriatric hospital. Rev Med Chil 2013;141:194-201.

27. Abraham FE, Varughese GL, Mathew JC, John PM, Sam GK. Drug utilization pattern among geriatric patients in a tertiary care teaching hospital. Asian J Pharm Clin Res 2015;8:191-4.
28. Atif M, Sarwar MR, Azeem M, Umer D, Rauf A, Rasool A, et al. Assessment of WHO/INRUD core drug use indicators in two tertiary care hospitals of Bahawalpur, Punjab, Pakistan. J Pharm Policy Pract 2016;9:1-8.

29. Taskeen M, Anitha N, Ali SR, Bharath R, Khan AB. A study on rational drug prescribing pattern in geriatric patients in Hyderabad metropolitan. J Drug Deliv Ther 2012;2:109-13.

30. Eze UI, Olowu AO. Prescribing patterns and inappropriate use of medications in elderly outpatients in a tertiary hospital in Nigeria. Trop J Pharm Res 2011;10:19-25.

31. Joshi MP, Sugimoto T, Santoso B. Geriatric prescribing in the medical wards of a teaching hospital in Nepal. Pharmacoepidemiol Drug Saf 1997;6:417-21.

32. Slabaugh SL, Maio V, Templin M, Abouzaid S. Prevalence and risk of polypharmacy among the elderly in an outpatient setting: A retrospective cohort study in the Emilia-Romagna region, Italy. Drugs Aging 2010;27:1019-28.

33. Van Der Hooft CS, Jong GW, Dieleman JP, Verhamme KM, Van Der Cammen TJ, Stricker BH, et al. Inappropriate drug prescribing in older adults: The updated 2002 Beers criteria-a population-based cohort study. Br J Clin Pharmacol 2005;60:137-44. 